6. Hijmans R.J. et al., 2002. Atlas of Wild Potatoes. IPGRI, Rome.

7. Muratova (Fadina) O.A. et al. South American species Solanum alandiae Card. and S.okadae Hawkes et Hjerting as potential sources of genes for potato late blight resistance. Труды по прикл. бот., ген. и сел. 2020. 181(1):73-83.

8. Клименко Н.С. и др. Маркер-опосредованная селекция отечественных сортов картофеля с маркерами генов устойчивости к золотистой картофельной нематоде (патотип Ro1). Труды по прикл. бот., ген. и сел. 2017. 178(4): 66-75.

9. Рогозина Е.В. и др. Каталог мировой коллекции картофеля ВИР. Картофель. Межвидовые гибриды картофеля устойчивые к возбудителям болезней. Вып. 833. СПб. ВИР. 2018.

DOI 10.18699/GPB2020-63

\title{
Разработка маркеров, контролирующих устойчивость ярового ячменя к патогену Cochliobolus sativus, на основе ассоциативного картирования
}

Розанова И.В. ${ }^{1,3 *}$, Лашина H.M. ${ }^{2}$, Ефимов B.M. ${ }^{3}$, Афанасенко O.C. ${ }^{2}$, Хлесткина E.K. ${ }^{1,3}$

${ }^{1}$ Федеральный исследовательский центр Всероссийский институт генетических ресурсов растений им. Н.И. Вавилова (ВИР), Санкт-Петербург, Россия;

${ }^{2}$ Всероссийский научно-исследовательский институт защчитьл растений, Санкт-Петербург, Россия;

${ }^{3}$ Федеральный исследовательский центр институт циттологии и генетики СО РАН, Новосибирск, Россия.

*e-mail:bykova@bionet.nsc.ru

Несовершенный гриб, патоген Cochliobolus sativus - (Bipolaris sorokiniana (anamorph) (Sacc) Shoemaker) это один из наиболее широко распространенных патогенов, вызывающий различные болезни, в числе которых темно-бурая пятнистость и корневые гнили. Определение генетических локусов, ассоцичрованных с устойчивостью ячменя к этим болезням, важно для разработки диагностических ДНК-маркеров для селекции устойчивых сортов ячменя. Целью настоящей работы является выявление генетических локусов, ассоциированные с устойчивостью как проростков, так и взросльх растений ячменя к изолятам C. sativus на основе оценки Сибирской коллекции ярового ячменя.

Ключевые слова: Hordium vulgare, QTL, Cochliobolus sativus.

The marker development that controlling the resistance of spring barley to Cochliobolus sativus pathogen using association mapping approach

Rozanova I.V. ${ }^{* 1,2}$, Lashina N.M ${ }^{3}$, Efimov V.M. ${ }^{2}$ Afanasenko O.S. ${ }^{3}$, Khlestkina E.K. ${ }^{1,2}$ 
${ }^{1}$ Federal Research Center N.I. Vavilov All-Russian Institute of Plant Genetic Resources (VIR); ${ }^{2}$ Federal Resaech Center Institute of Cytology and Genetics SB RAS, Novosibirsk, Russia; ${ }^{3}$ All-Russian Research Institute for Plant Protection, St. Petersburg, Russia.

*e-mail: bykova@bionet.nsc.ru

The fungal pathogen Cochliobolus sativus - (Bipolaris sorokiniana (anamorph) (Sacc) Shoemaker) is one of the most worldwide pathogen which causes such diseases as spot blotch and root rot of barley. Identification of genetic loci associated with resistance to $C$. sativus is of importance for future marker-assisted selection. The goal of the current study was to identify loci conferring both for seedling and for adult plants resistance to different isolates of $C$. sativus pathogen in the Siberian spring barley core collection.

Селекционные программы по созданию новых сортов злаковых растений ориентированы на сохранение урожая и экологичности его получения. Одним из компонентов этих программ является выведение сортов злаковых, устойчивых к болезням. В конце прошлого века благодаря появлению и быстрому развитию технологий секвенирования и молекулярного картирования появились подходы, основанные на применении ДНК-маркеров в селекции. Маркер-ориентированная селекция (МOC) позволяет ускорять и удешевлять процесс получения сорта путем более быстрого и эффективного отбора нужных генотипов среди селекционных гибридов. Геномная селекция позволяет оценивать потенциал вклада небольших по эффективности QTL. ДНК-маркеры перспективны в создании сортов с долгосрочной устойчивостью, так как их использование дает возможность комбинировать гены устойчивости в одном генотипе, обеспечивая тем самым эффективную защиту против широкого спектра изолятов с различной вирулентностью $[1,2]$. МОС с использованием маркеров, генов устойчивости растений к болезням, широко используются в Европе, США, Канаде и Австралии. Применение этого подхода является актуальным и для России. Одной из основных болезней ячменя, наносящих серьезный урон урожаю во всех регионах его культивирования, является темно-бурая пятнистость (вызываемая аскомицетом Cochliobolus sativus, анаморфа Bipolaris sorokiniana). Эпифитотии пятнистостей ячменя случаются раз в 5-10 лет. Снижение урожайности сортов ячменя восприимчивых к этим болезням во время эпифитотии составляют от 20 до 40 \% $[1,3]$. Патоген C.sativus вызывает не только темно-бурую пятнистость, но так же и корневые гнили. При серьезном поражении корневыми гнилями результатом является укорочение колоса, самого растения и уменьшение зерна, что также приводит к снижению урожайности. Потери урожая могут достигать $80 \%$ [4].

В настоящее время для выявления генетических маркеров, ассоции- 
рованных с устойчивостью используют два подхода: анализ двуродительских картирующих популяций и анализ коллекций с помощью полногеномного анализа ассоциаций (GWAS). QTL анализ 12 двуродительских картирующих популяций выявил ранее ряд локусов, связанных с устойчивостью к темно-бурой пятнистости на всех хромосомах ячменя [3, 5-9]. Ассоциативное картирование локусов, отвечающих за данный признак, также успешно использовалось для выявления новых локусов в коллекциях образцов ячменя различного происхождения [10-14]. Данных по картированию локусов устойчивости к корневым гнилям не обнаружено. Отечественный генофонд, в подобных исследованиях практически не был задействован. В связи с этим целью настоящей работы было выявление генетические маркеры как ювенильной устойчивости, так и взрослых растений к темно-бурой пятнистости, и к корневым гнилям на основе ассоциативного картирования с использованием Сибирской коллекции ярового ячменя.

Экспериментальная часть. В 2017 году было проведено высокопроизводительное SNP-генотипирование 94 отобранных сортов и линий ячменя Сибирской коллекции по технологии 50,000 Иллюмина iSeect SNP анализа в компании Traitgenetics GmbH (Gatersleben, Germany) по 44,040 SNP маркерам. Из 44 тыс. SNP около 39 тыс. были полиморфными, из них для полногеномного анализа ассоциаций использовались 62 \% наиболее информативных [15].

Оценку устойчивости проростков к возбудителям темно-бурой пятнистости проводили с помощью трех изолятов C. sativus различного происхождения: Ch3, Kr2 и O18.2. Так же оценку устойчивости к взрослым растениям проводили с помощью изолята $\mathrm{Ch} 3$. Оценку устойчивости к проросткам к корневым гнилям проводили с помощью изолята О18.2.

Результаты исследования. Согласно литературным данным не было выявлено значимой корреляции между корневыми гнилями и темно-бурой пятнистостью листьев [16-17].

В данной работе корреляция показателей между устойчивостью к корневым гнилям и устойчивостью к темнобурой пятнистости колеблется в районе от 0,221452 до 0,2813. Такое значение говорит о слабой корреляции между устойчивостью к двум болезням. Корреляция между показателями устойчивости к различным изолятам для проростков была достаточно высокой (от 0,609647 до 0,729975). Корреляция между устойчивостью проростковой стадии и стадии взрослых растений оказалась слабее: взрослые растения были инфицированы изолятом Ch3 и корреляция между показателями для проростков инфицированных с Ch3 и взрослыми растениями составила 0,5688.

Выявлены 7 участков генома, ассоциированные с проростковой устойчивостью ячменя к темно-бурой пятнистости. Только 1 значимый SNP на 5 хромосоме был ассоциирован с устойчивостью взрослых растений. Значимых SNP к корневым гнилям выявлено не было. 
По полученным данным 12 значимых SNP (на 1, на 3 , на 5 и на 7 хромосомах) были конвертированы в KASP маркеры. Для подтверждения или опровержения KASP маркеры исследовались на независимой выборке, состоявшей из 22 сортов, контрастных по устойчивости к темно-бурой пятнистости (11 устойчивых и 11 восприимчивых сортов). Устойчивые/Вос-приимчивые сорта были получены из ВИЗР. По данным KASP генотипирования 6 маркеров, расположенные на 3 хромосоме были подтверждены на независимой выборке и их можно исследовать дальше как потенциальные диагностические маркеры для выявления сортов устойчивых к темно-бурой пятнистости.

Полученные маркеры могут быть использованы для отбора селекционного материала, несущего нужные аллели в локусах устойчивости к темно-бурой пятнистости. 14-00086).

Благодарности: Работа выполнена при поддержке РНФ (грант № 16-

\section{Список литературы}

1. Shjerve R.A., Faris J D., Brueggeman R.S., Yan C., Zhu Y., Vaidehi Koladia V., Friesen T.L. Evaluation of a Pyrenophora teres f. teres mapping population reveals multiple independent interactions with a region of barley chromosome $6 \mathrm{H}$. Fungal Genetics and Biology 70 (2014) 104-112.

2. Islamovic E., Bregitzer P., Friesen T. L. Barley 4H QTL confers NFNB resistance to a global set of P. teres f. teres isolates //Molecular Breeding. - 2017. - T. 37. - №. 3. C. 29.Steffenson BJ, Hayes PM, Kleinhofs A. Genetics of seedling and adult plant resistance to net blotch (Pyrenophora teres f. teres) and spot blotch (Cochliobolus sativus) in barley. Theor Appl Genet. 1996;92:552-8.

3. Afanasenko OS, Koziakov AV, Hedlay PE, Lashina NM, Anisimova AV, Manninen O, Jalli M, Potokina EK. Mapping of the loci controlling the resistance to Pyrenophora teres F. teres and Cochliobolus sativus in two double haploid barley populations. Russ. J. Genet. Appl. Res. 2015;5:242-53.

4. Piening L., Orr D. Effects of crop rotation on common root rot of barley. Canadian Journal of Plant Pathology. 1988;10(1):61-65.

5. Steffenson B.J., Hayes P.M., Kleinhofs A. Genetics of seedling and adult plant resistance to net blotch (Pyrenophora teres $\mathrm{f}$. teres) and spot blotch (Cochliobolus sativus) in barley. Theor Appl Genet. 1996;92:552-8.

6. Bilgic H, Steffenson B, Hayes P. Comprehensive genetic analyses reveal differential expression of spot blotch resistance in four populations of barley. Theor Appl Genet. 2005;111:1238-50.

7. Bovill J, Lehmensiek A, Sutherland MW, Platz GJ, Usher T, Franckowiak J, Mace E. Mapping spot blotch resistance genes in four barley populations. Mol Breed. 2010;26:653-66.

8. Grewal TS, Rossnagel BG, Scoles GJ. Mapping quantative trait loci associated with spot blotch and net blotch resistance in a doubled-haploid barley population. Mol Breed. 2012;30:267-79.

9. Haas M, Menke J, Chao S, Steffenson BJ. Mapping quantitative trait loci conferring resistance to a widely virulent isolate of Cochliobolus sativus in wild barley accession 
PI 466423. Theor Appl Genet. 2016;129:1831-42.

10. Roy JK, Smith KP, Muehlbauer GJ, Chao S, Close TJ, Steffenson BJ. Association mapping of spot blotch resistance in wild barley. Mol Breeding. 2010;26:243-56.

11. Zhou H, Steffenson BJ. Genome-wide association mapping reveals genetic architecture of durable spot blotch resistance in US barley breeding germplasm. Mol Breed. 2013;32:139-54.

12. Berger GL, Liu S, Hall MD, Brooks WS, Chao S, Muehlbauer GJ, Baik BK, Steffenson B, Griffey CA. Marker-trait associations in Virginia Tech winter barley identified using genome-wide mapping. Theor Appl Genet. 2013;126:693-710.

13. Gutiérrez L, Berberian N, Capettini F, Falcioni E, Fros D, Germán S, Hayes PM, Huerta-Espino J, Herrera S, Pereyra S, Pérez C, Sandoval-Islas S, Singh R, Castro A. Genome-wide association mapping identifies disease-resistance QTLs in barley germplasm from Latin America. In: Zhang G, Li C, Liu X, editors. Advance in barley sciences. Proceedings of 11th international barley genetics symposium; 2013. p. 209-15.

14. Wang R, Leng Y, Ali S, Wang M, Zhong S. Genome-wide association mapping of spot blotch resistance to three different pathotypes of Cochliobolus sativus in the USDA barley core collection. Mol Breed. 2017;37:44.

15. Bykova I.V., Lashina N.M., Efimov V.M., Afanasenko O.S., Khlestkina, E.K. Identification of $50 \mathrm{~K}$ Illumina-chip SNPs associated with resistance to spot blotch in barley.BMC plant biology, 2017;17(2):250.

16. Kutcher H.R., Bailey K.L., Rossnagel B.G., Legge W.G. Heritability of common root rot and spot blotch resistance in barley. Canadian journal of plant pathology, 1994;16(4):287-294.

17. Almgren I., Gustafsson M., Lindgren H., Liljeroth E. Interaction between root and leaf disease development in barley cultivars after inoculation with different isolates of Bipolaris sorokiniana. Journal of Phytopathology,1999;147(6):331-337.

DOI 10.18699/GPB2020-64

\section{Молекулярно-генетический полиморфизм возбудителя листовой ржавчины на твердой пшенице в Казахстане}

Рсалиев А.С. ${ }^{*}$, к.с.-х.н., зав. лаб.; Шайдаюк Е.Л. ${ }^{2}$, м.н.с.; Кохметова А.М. ${ }^{3}$, д.б.н., зав. лаб.; Гультяева Е.И. ${ }^{2}$, о.б.н., в.н.с.

${ }^{1}$ Научно-исследовательский институт проблем биологической безопасности, Гвардейский, Казахстан;

${ }^{2}$ Всероссийский НИИ зашиты растений, Санкт-Петербург, Россия;

${ }^{3}$ Институт биологии и биотехнологии растений, Алмать, Казахстан, *e-mail: aralbek@mail.ru

Изучена вирулентность и полиморфизм микросателлитных локусов у изолятов Риссіпіа triticina, выделенных с яровой твердой пшеницыь, вырашиваемой в Южном Казахстане в 2018 и 2019 га. Выявлены различия в виру- 